\title{
O Turismo Rural em Panambi/RS
}

\author{
The Rural Tourism In Panambi/RS \\ ${ }^{1}$ Artigo elaborado a partir da Monografia do Curso de Graduação em Geografia-UNIJUI-RS \\ ${ }^{2}$ Denise Miriam Neumann dos Santos ( Trabalha no Museu e Arquivo Histórico Panambi/RS).
}

\section{Resumo}

O presente trabalho teve como objetivo observar e analisar as práticas, opções e possibilidades do Turismo Rural, tendo como lócus de estudo o município de Panambi/RS, localizado no noroeste do Rio Grande do Sul. Em termos teórico-metodológicos, foi realizado um estudo a campo, buscando conhecer as práticas de turismo rural existentes, bem como mapear novas possibilidades. Essa pesquisa trata da questão espacial, resultado da relação natureza e sociedade, específica do lugar, com ênfase ao estudo das opções turísticas no espaço receptor do município, temática importante dada a sua relevância e atualidade, no contexto socioespacial deste século, investigando as possibilidades e alternativas para o desenvolvimento do turismo rural de Panambi. O turismo precisa ser conciliado com as atividades agropastoris e deve estar atento aos quatro pilares que o fundamentam: ser ecologicamente correto, ser economicamente viável, ser socialmente justo e ser verdadeiramente rural. Segundo Swarbrooke (2000), o turismo rural pode ser chamado, efetivamente, de turismo rural sustentável quando for estimulador da compreensão sobre os impactos que poderá causar nos ambientes.

Palavras chave: turismo - desenvolvimento - sustentabilidade

\begin{abstract}
This paper aims to observe and analyze the practices, options and possibilities of Rural Tourism, with the study of the municipality of locus Panambi / RS, located in the northwest of Rio Grande do Sul. In theoretical and methodological terms, there was a study the field, getting to know the existing rural tourism practices, as well as to map new possibilities. This research deals with the space issue, a result of the relationship nature and society, specific place, emphasizing the study of tourist options in the receiving space of the city of Panambi important issue given its importance and relevance in the socio-spatial context of this century, investigating the possibilities and alternatives for the development of rural tourism Panambi. Tourism needs to be reconciled with the agropastoral activities and be aware of the four pillars which it is based: being environmentally friendly, economically viable, socially just be and be truly rural. According Swarbrooke (2000), rural tourism can be called effectively for sustainable rural tourism when stimulating the understanding of the impacts that could result in the environments
\end{abstract}

Keywords: tourism - development - sustainability 


\section{Introdução}

Este artigo foi apresentado no III Congresso Internacional de Educação Ambiental/Curso de Especialização em Educação Ambiental - UFSM Pólo Presencial UAB Panambi/RS e IX Seminário Municipal do Meio Ambiente. Teve como lócus de estudo o município de Panambi/RS, com o objetivo de observar e analisar as práticas, opções e as possibilidades do Turismo Rural neste município. O advento do século XXI trouxe várias mudanças na relação do homem com a natureza, como a busca por novas opções de lazer. Nesse contexto, podemos incluir o Turismo Rural, o qual atrai um público considerável e crescente. Esta modalidade de turismo inclui passeios noturnos e diurnos no meio rural, visitas, hospedagem e inserção em atividades nas propriedades rurais. Também visa à preservação e conservação do meio ambiente rural. Segundo Swarbrooke (2000), o turismo rural pode ser chamado, efetivamente, de turismo rural sustentável quando for estimulador da compreensão sobre os impactos que poderá causar nos ambientes: natural, cultural e humano.

O turismo sustentável esta relacionado com as necessidades básicas do homem, não se referindo somente aos recursos naturais. A sustentabilidade da atividade turística deve ter como alicerces o meio ambiental, econômico e social. Deve se desenvolver, porem precisa manter um constante compromisso com a conservação ambiental. Formar cidadãos turistas conscientes, comprometidos com a preservação do meio ambiente.

\section{Referencial teórico}

A geografia do turismo possui inúmeras definições, mas ainda, é motivo de debates e polêmicas. Segundo o organismo oficial do setor, a Organização Mundial de Turismo (OMT), o turismo é uma modalidade de deslocamento espacial, que envolve a utilização de algum meio de transporte e ao menos um pernoite no destino. Já para Rita de Cássia Ariza da Cruz, o turismo é uma prática social que vem mudando de sentido ao longo da história e cada nova definição consiste em nova tentativa de se conceituar algo que tem, reconhecidamente, uma dinâmica inquestionável.

Procura novas atividades para as horas de lazer das pessoas de uma forma mais moderna, levando a um desenvolvimento alternativo, firmado em bases educativas, sempre preservando e conservando a natureza e a cultura dos lugares.

O turismo também engloba diversas formas como o turismo em massa, que mobiliza grandes contingentes de viajantes. Já o turismo alternativo ou turismo de natureza, ecológico ou ecoturismo tem seu principal objeto de consumo nos espaços naturais. Por sua vez, o lugar turístico; atrativos turísticos são aqueles inventados culturalmente. Enfim, a paisagem turística é tudo que nossos olhos podem ver no espaço geográfico.

Em espaços rurais projetou-se a partir da década de 60. Teve suas origens, segundo Portuguez (1999), na prática da hospedagem em propriedades rurais, cuja gênese está associada a necessidade de abrigar viajantes que circulavam por regiões norte-americanas pouco povoadas e, ao mesmo tempo, de paisagens consideradas atrativas para o turismo. A inexistência de meios de hospedagem nessas áreas teria instigado proprietários de fazendas, residentes nessas regiões, a abrir suas propriedades para o pouso daqueles viajantes.

O turismo rural é a apropriação de um espaço da dimensão do espaço geográfico que pode ser modificado, receber infraestruturas, abarcar a visitação a propriedades rurais com pernoite ou não. Ele pode ser também uma fonte de renda para pequenas propriedades rurais.

Um projeto com um roteiro muito bem elaborado e estruturado pode trazer muitos benefícios a uma cidade, pois a principal fonte de consumo do turismo é o espaço geográfico, o qual geralmente passa por adaptações ou modificações para receber os turistas. O turismo cria seus próprios espaços, bem como toma posse de rodovias para seu deslocamento. Segundo Rita 
C. A. da Cruz (p.25) o turismo cria novos objetos nos lugares, mas também se apropria de objetos preexistentes, como objetos naturais (rios, praias, montanhas etc.) e objetos culturais (infraestruturas, edifícios, patrimônio histórico), atribuindo-lhes novos significados e, muitas vezes, novas feições.

O espaço ganha novas formas ou adaptações para que o turista se sinta bem acolhido, mas nunca perdendo a essência, ou o real motivo daquele turismo.

\section{Metodologia}

O trabalho foi realizado a partir de revisão bibliográfica, coleta de informações em jornais e páginas da internet e pesquisa de campo, buscando conhecer o que é o turismo rural em Panambi/RS, as opções e lugares da oferta turística e perspectivas de novos empreendimentos.

\section{Resultados e discussões}

A Geografia é fundamental para o estudo do turismo, pois este é geográfico em sua natureza. $\mathrm{O}$ turismo acontece em lugares, envolvendo os movimentos e as atividades entre estes lugares, sendo uma atividade onde tanto as características locais quanto as identificações pessoais são formadas, através das relações criadas entre estes lugares, paisagens e pessoas.A preocupação central da Geografia do turismo são os impactos socioambientais decorrentes desta atividade.

O estudo do turismo pela Geografia é uma de suas temáticas na análise da organização espacial. Nesta perspectiva, considera-se o arranjo espacial dos lugares turísticos ou espaço receptor, as densidades dos fixos e fluxos e suas conexões com os espaços emissores, ou seja, quais as formas espaciais usadas ou criadas para atender a função turística. Revelam-se como serviço público ou privado para atender a oferta específica de um tipo de turismo, no contexto do desenvolvimento de uma comunidade local/regional na atualidade.

Dentre as diferentes manifestações turísticas (turismo ecológico, ecoturismo, turismo solpraia, turismo religioso...), consagra-se cada vez mais o que podemos denominar de turismo rural. A valorização da paisagem rural como recurso histórico, conforme Pires, da-se pela humanização da natureza por meio de atividades agropastoris e de outros aspectos da ocupação do espaço, impregnados pela herança cultural de seus protagonistas (Rodrigues, 2002 p. 117).

O desenvolvimento do turismo rural, no Brasil, não se constitui num fenômeno de grandes proporções, mas está se constituindo como alternativa de opção turística, com periodicidade diversa da sazonalidade que caracteriza o turismo sol-praia, podendo realizar-se o ano todo.

O turismo hoje contribui com uma parcela de 10\% no PIB mundial (dados apresentados pelo ministro do turismo Walfrido dos Moraes Guia, em 2003). Isto comprova o importante papel que o turismo vem exercendo na geração de novos empregos e no fortalecimento da economia.

Mas o turismo também apresenta pontos negativos como os custos de cunho cultural, social e o ambiental.

A visitação às localidades pode gerar renda e desenvolvimento, mas geralmente o turista ignora certos preceitos básicos de preservação que geram impactos bastante negativos no meio ambiente. É preciso muito estudo e reflexão sobre a sustentabilidade, perceber a relação sociedade e natureza, as questões ambientais e ecológicas e os projetos turísticos nas áreas rurais para que os impactos negativos não sejam tão agressivos. Para tanto é necessário planejar, colocar em pauta os interesses das comunidades, organizar discussões em relação aos custos e benefícios em nível econômico, social, ambiental e antrópico, para não deixar que se alastre a degradação e a perda de qualidade dos recursos naturais, para que os impactos socioambientais sejam mínimos. 
Para que o turismo possa acontecer é preciso entender as estruturas produtivas do campo que devem adaptar-se a ele e apresentar definições quanto ao tipo de exploração turística rural, estar preparada para receber o produto turístico, fazer as adaptações necessárias e definir as estratégias de marketing e comercialização.

O Ministério do Turismo considera como estratégia para esse fim:

- compatibilização da conservação e o desenvolvimento dos recursos turísticos; escalas;

- criação de uma oferta de alojamento e recreação não concentradas e em pequenas

- contato com a natureza;

- organização e a gestão do turismo realizado pela população campesina.

Ou seja, é preciso muito planejamento para que o turismo aconteça de forma sustentável e correta, sempre tendo em vista o bom atendimento ao seu consumidor, o turista.

$\mathrm{O}$ turismo precisa ser conciliado com as atividades agropastoris e estar atento aos quatro pilares que o fundamentam: ser ecologicamente correto, ser economicamente viável, ser socialmente justo e ser verdadeiramente rural.

Além desses quatro pilares, existem outras características que são fundamentais e que devem ser observadas, como a propriedade em si e suas instalações que precisam ser adaptadas, porém tentando-se sempre manter o mais original possível, estar em harmonia com a comunidade local, com o meio ambiente e com a cultura regional, não deve ser massiva como ocorre no litoral, o atendimento ao turista deve ser familiar e pessoal, promover a fixação do homem no campo e sempre procurar resgatar a riqueza e as variedades da cultura do meio rural, promovendo agregação de valor aos produtos oriundos do campo.

Como já mencionado, o turismo traz muitos pontos positivos, mas também tem os pontos negativos, onde podemos destacar como principais a degradação de ambientes naturais, abandono das atividades tradicionais por parte da população local, substituição de tipologias tipicamente urbanas para o espaço rural, deterioração da cultura autóctone, aparecimento de tensões e animosidades entre vizinhos e turistas, e padronização dos modos de vida, perdendo-se o caráter rural e apropriando-se do das populações urbanas.

Segundo Swarbrooke (2000), o turismo rural pode ser chamado, efetivamente, de turismo rural sustentável quando for estimulador da compreensão sobre os impactos que poderá causar nos ambientes: natural, cultural e humano; quando for estimulador da justa distribuição de benefícios e custos, quando for o gerador de empregos locais -diretos e indiretos -, quando for estimulador de indústrias domésticas como: agroindústrias, hotéis e outros tipos de alojamentos, restaurantes e outros serviços, por exemplo, alimentação, sistemas de transporte, artesanato e serviços de guias locais de forma compatível com a sustentabilidade, quando diversificar a economia das áreas rurais, quando encorajar o uso produtivo de terras consideradas marginais para a agricultura, permitindo a conservação de grandes áreas com cobertura vegetal original e quando intensificar a autoestima das comunidades locais, oferecendo oportunidades de maior compreensão e comunicação entre a população rural e urbana.

O município de Panambi faz parte da Região Noroeste Colonial do Rio Grande do Sul. Essa região é composta pelos Coredes Noroeste Colonial, Fronteira Noroeste e Celeiro, num total de 52 municípios, abrangendo um total de $14.620 \mathrm{Km}^{2}$, e uma população de mais de 500.000 habitantes.

O turismo rural no município de Panambi ainda está sendo pouco explorado, talvez um dos motivos seja a falta de demanda de público, pois a grande maioria da população possui alguém na família que mora no meio rural, facilitando o acesso ao mesmo de forma gratuita e indeterminada, ou ainda a falta de interesse tanto da população bem como dos órgãos responsáveis, pois já existem hoje políticas a favor, inclusive projetos para solicitação de recurso da união.

O que acontece no município é o turismo em áreas rurais, este sim vem sendo explorado, como o caso dos balneários, com piscinas, camping, estruturas inclusive para eventos, as tradicionais áreas de lazer, onde turista passa o dia desfrutando de diversas opções. 
Partindo do levantamento de dados, fica registrado que o município de Panambi apesar do grande potencial turístico rural ainda está sendo pouco explorado. Não se tem dado a atenção necessária para este ramo, e conseqüentemente muita coisa está se perdendo ou já se perdeu. A grande maioria das construções que remetem às décadas de 10, 20 e 30, que são de uma beleza extrema, está em ruínas ou já foram demolidas e suas terras utilizadas para o cultivo.

\title{
5 Conclusão
}

A partir dos dados apresentados conclui-se que o turismo é um fenômeno social, que está em amplo crescimento no início do século XXI.

Para a Geografia os estudos voltados para o turismo são fundamentais, pois este é geográfico em sua natureza. Esse interesse se intensificou a partir da década de 60 , com o intuito de conhecer e explicar as atitudes e os valores de uma comunidade frente ao meio ambiente, tendo como foco principal o espaço. O mesmo espaço que compõem os aspectos físicos, e o mesmo espaço ocupado pelas vivências humanas também é ocupado pelos turistas.

Para que possamos obter resultados positivos dessa atividade, é preciso manter um olhar sobre a geografia do turismo através da distribuição dos impactos e demais variáveis sobre o meio ambiente, pois o maior desafio da geografia do turismo é o de conferir quais são as dimensões geográficas desta atividade, considerando que a mesma possui um caráter transversal e interdisciplinar, a par da diversidade da sua topologia.

$\mathrm{O}$ turismo vem crescendo rapidamente no mundo todo, garantindo lugar entre as principais atividades geradoras de receita aos municípios e/ou proprietários. Também é fundamental para o desenvolvimento da sociedade, necessitando assim de mais estudos e pesquisa, por ser uma realidade econômica, social, cultural e política. O turismo tem suas características voltadas a momentos de descanso, lazer, repouso, longe do ambiente de trabalho, a possibilidade que os seres humanos encontram de sair da rotina.

Segundo a Organização Mundial do Turismo (OMT),

\begin{abstract}
O turismo é uma modalidade de deslocamento espacial, que envolve a utilização de algum meio de transporte e ao menos um pernoite no destino; esse deslocamento pode ser motivado pelas mais diversas razões, como lazer, negócios, congressos, saúde e outros motivos, desde que não correspondam a forma de remuneração direta.
\end{abstract}

A OMT sugere ainda que viagem e turismo são sinônimos, por toda viagem ser considerada turismo, inclusive quando se trata em cuidar da saúde.

O turismo é motivado pelos atrativos apresentados em determinados lugares, sendo classificados como o lugar turístico, o atrativo turístico e a paisagem turística. Para que o turismo aconteça, o espaço turístico também precisa estabelecer a ligação entre o local e o global, disponibilizando as condições mínimas de infraestrutura para o conforto do turista.

O Turismo Rural ou uma nova ruralidade também vem desenvolvendo um papel de destaque no setor econômico, principalmente para pequenos ou médios produtores rurais, que estão buscando novas opções de renda para garantir o sustento e a permanência no meio rural. $\mathrm{O}$ produtor tem a possibilidade de manter sua produção e juntamente a chance de obter mais renda, além de gerar empregos, conscientiza a população na conservação e preservação do meio ambiente. Buscando valorizar sempre a cultura local ou regional.

E além do turista ter a oportunidade de acompanhar as atividades do meio rural também pode adquirir os produtos produzidos pelo agricultor diretamente na propriedade, garantindo qualidade e bom preço.

O que mais atrai os turistas hoje para o turismo rural é o modo simples de vida que se leva no meio rural, as suas características próprias e particularidades, ou seja, quanto mais natural a propriedade for, mais atrativa será. 
Apesar dessas discussões teóricas, na prática, como foi apontado, o turismo rural apresenta diversas vantagens ao produtor rural, mas também possui aspectos negativos principalmente em relação ao cuidado e a preservação com o meio ambiente, pois o turismo muitas vezes acaba ignorando certos preceitos básicos, principalmente na produção e destino incorreto do lixo produzido. O produtor também precisa estar preparado, ou seja, as estruturas produtivas do campo devem se adaptar a ele e apresentar definições quanto ao tipo de exploração turística rural e fazer as adaptações necessárias, definindo as estratégias de marketing e comercialização.

\section{Referências} Roca, 2003.

CRUZ, Rita de Cássia Arizada. Introdução à geografia do turismo.2.ed. São Paulo: 2001.

CRUZ, Rita de Cássia. Política de Turismo e Território. 2 ed. São Paulo: Contexto,

NEUMANN, Rosane Márcia. Uma Alemanha em Miniatura: O Projeto de Imigração e Colonização Étnico Particular da Colonizadora Meyer no Noroeste do Rio Grande do Sul (1897-1932). Porto Alegre 2009. Dissertação (Doutorado). Programa de Pós-Graduação em História. PURCS, 2009.

PORTUGUEZ, Anderson Pereira - Agroturismo e desenvolvimento regional. São Paulo, Editora Hucitec, 1999.

PIRES, Paulo dos Santos. A paisagem rural como recurso turístico. In; RODRIGUES, Adyr B. (org.) Turismo Rural. São Paulo: Contexto, 2001.

RODRIGUES, Adyr Balastreri (org.) Turismo Rural: Práticas e Perspectivas. São Paulo: Contexto, 2001.

SWARBROOKE, J. Turismo sustentável: conceitos e impacto ambiental, v.1. tradução Margareth Dias Pulido. São Paulo: Aleph, 2000. 